\title{
Review Article European Museums, Migration, and Social Inclusion
}

Amy K. Levin*

Innocenti, Perla, ed. Migrating Heritage: Experiences of Cultural Networks and Cultural Dialogue in Europe. Farnham, Surrey: Ashgate, 2014, hardback £63, pp. xxx+302.

\author{
Whitehead, Christopher, Katharine Lloyd, Susannah Eckersley, and Rhiannon Mason \\ (eds.), Museums, Migration and Identity in Europe, Farnham, Surrey: Ashgate, 2015, \\ hardback $£ 70$, pp.xx+325.
}

The year of 2015 will remain in history as a time that saw population movements in Europe unrivaled since the end of the Second World War. In June, the photographs of migrant camps in and around Milan filled news reports. In July, we saw spectacles of migrants in and around the Channel tunnel; August brought drowned children near the Greek isle of Kos, and September bore witness to walls and armed clashes in Eastern Europe. In this sea of dispiriting events, one of the rare positive news accounts relating to migrants focused on a museum; a very small museum to be precise, one that is largely unknown. Even its physical location is difficult to trace. Binario 21 (or track 21) is the site where Milan's Jews were shipped off to the concentration camps in Eastern Europe during the Second World War. This dark and mostly empty space, which contains two of the original boxcars, is situated beneath Milano Centrale Station. Trains rumble overhead, while the plaza in front of the Mussolini Modern edifice is filled with migrants, eating, sleeping, hanging out laundry, playing with their children, bathing.

The silence and darkness of Binario 21 alone would be an effective testament to the horrors of deportation as a form of coerced migration. But the museum acquired new resonance in July 2015. The site's organizers and sponsors enacted their commitment to social justice by transforming the coatroom into a nightly shelter for North African migrants. Cots were installed, along with showers in the visitor toilets. Kosher food was provided by a Jewish charity. A Catholic community, Sant'Egidio, which has been a partner to the institution since its founding, provided volunteers. The space, a transitional site in the 1940s and again seventy-five years later, offered safety and comfort to individuals who awaited a resolution to the impasse at Italy's borders. But it also offered a startlingly innovative example of how museums may adapt an activist position.

The year 2015 is also significant for museums and migration because it marks the end of the European Union-funded MeLA (European Museums in an Age of Migrations) programme. ${ }^{1}$

The MeLA project aimed to study migration museums in Europe from multiple angles, as well as to publicize best practices and make recommendations for the future. Both of the books reviewed in this article grew out of the MeLA project and the broader European concern with growing numbers of migrants: Perla Innocenti's edited volume, Migrating Heritage, stemmed from research field 3 (Network of Museums, Libraries, and Public Cultural Institutions) while Museums, Migration and Identity in Europe, edited by Christopher Whitehead, Katharine Lloyd, Susannah Eckersley, and Rhiannon Mason, developed from the first research field (Museums and Identity in History and Contemporaneity). Both edited volumes provide a variety of perspectives on existing institutions and initiatives. They draw the spotlight away from large, well-known institutions dedicated primarily to migration, such as Ellis Island or the Red Star 
Line Museum, to institutions that have a more general focus, such as the Museum of London. Other institutions are less well known. The relevant exhibitions concentrate mostly on settlers. These museums are less interested in acts of arrival and departure than in the daily lives of immigrants and their descendants, their contributions to their new homes, and the ways in which nations welcome or marginalize diverse populations.

Following Museums and Migration: History, Memory and Politics by Laurent Gourividis (Abingdon, Oxon.: Routledge, 2014), these titles draw attention to a defining characteristic of our time. Innocenti sets her book apart by focusing on the notion of 'migrating heritage' less as the heritage of migrants than as the heritage that migrates with people. Whitehead et al adopt a narrower focus than Gouriévidis, who covers a few institutions beyond Europe and emphasizes migration narratives. Moreover, Whitehead et al stress the importance of mapping and place.

The key contribution of Innocenti's text is the exploration of networks and exchanges as they affect museums' work regarding migration. Chapters at the end of the book, such as Jacopo Leveratto's 'Library and Museum Hybridisation: Ultimate Spatial Forms of Institutional Collaboration in the Process of Identity Representation' address the role of libraries. Archives and digital networks constitute the topics of other chapters, such as 'Europeana: Cultural Heritage in the Digital Age,' by Eleanor Kenny. The text also focuses on cultural dialogue and exchange as tools for creating social inclusion, for instance, in Domenico Sergi's article, 'Critical Objects: Museums, Refugees and Intercultural Dialogue' or 'A Curious Case Study: Creating Intercultural Dialogue through Objects,' by Aileen Strachan. In addition to providing rich examples of practices across Europe, the book offers practical information for practitioners. David Gauthier, Jakob Bak and Jamie Allen propose 'Visualising Interdisciplinary Research: Algorithmic Treatment of Museum Case-Study Information Sets,' is one case. 'Migrations and Multiculturalism: A Design Approach for Cultural Institutions,' by Eleonora Lupo, Lucia Parrino, Sara Radice, Davide Spallazzo, and Raffaella Trocchianesi, provides useful and clearly delineated categories. First, it distinguishes between and among 'multicultural storytelling,' 'intercultural dialogue,' and 'transcultural practice.' This is followed by a design schema, which considers 'operative models' for using digital technologies, for instance, 'performing heritage,' or 'multifaceted heritage' (65-77). These models are then analyzed for the extent to which they involve 'cultural contents,' 'space,' or 'social relations' (65-77).

Readers might wish that several chapters that comprise five to ten pages included more extensive discussion. They may also notice that in rare cases, the authors of individual chapters maintain stances of privilege toward those they claim as partners. For example, in '"Roma Routes": Heritage as a Path to Dialogue,' the author comments, 'There were some members (Roma and non-Roma) who were less used to the forms of behaviour used in formal meeting situations' (146). One wonders whether a similar statement might have been included in an article about a group of middle class women presiding over a historic home museum. 'On Their Own: Telling Child Migrant Stories in a Transnational Context,' by Kim Tao, asserts rightly that child migrations have received little attention of their own in museums. Yet the emphasis on 'child migrants as victims of oppression in spite of rough beginnings, [who] have made positive contributions to society, 'is somewhat problematic. The affirmative perspective is welcome because it counters the stereotype of the shiftless, delinquent immigrant adolescent. Yet this stance raises an equal risk of creating an expectation that, to be accepted, migrants must be able to raise themselves by their proverbial bootstraps and excel according to the standards of the host society.

The two collections overlap when they discuss identities and city museums. Nevertheless, Museums, Migration and Identity in Europe contributes to the knowledge base in its own way. The book is more deeply embedded in the MeLA framework and related to an earlier work, Placing Migration in European Museums: Theoretical and Methodological Orientations, edited by Whitehead, Eckersley, and Mason in 2012 and published by the Politcenico of Milano, which hosted the MeLA project. The newer work stands on its own as well, and indeed, one of its great strengths is the way in which the chapters refer to each other and theoretical concepts are woven throughout. As an example, several chapters provide perspectives on museums in Amsterdam. The central organizing principle in the book is the notion of place: 
Through this force, migration and related issues such as ideas of belonging, disadvantage and prejudice can be presented as historicized phenomena that involve antagonisms to be faced in the present. At the same time, the repositioning of place means that the inevitable political agency of the museum can be both problematized and reflexively mobilized to engage with socio-political debates, tensions and possibilities (7).

As places, museums themselves participate in 'cultural cartography' of layered space: the physical environment of the exhibition, as well as the historical places represented (13). The interactions between the two create tensions that are necessary for understanding the intersecting roles of migration, nation-building, and social inclusion.

Annemarie de Wildt's chapter, 'From Multiculturalism to (Super) diversity: Examples from the Amsterdam Museum,' includes several positive contributions. The author addresses the challenges museums face in an era of superdiversity, when it is no longer practicable for a museum to tell the stories of all the migrant groups in a metropolitan area. Moreover, a focus on commonalities or a celebration of immigration may neglect or ignore histories of racism and social exclusion. De Wildt succeeds in providing a nuanced analysis that draws readers' attentions to the successes and failures of the exhibitions she discusses. The article is particularly useful because it constantly returns to the importance of engaging new audiences in museums that have been accustomed to catering to predominantly white audiences.

The chapter by Whitehead and Gönül Bozoğlu, 'Constitutive Others and the Management of Difference: Museum Representations of Turkish Identities,' the penultimate piece in the collection, is in many ways its culmination. Mentioned frequently in earlier articles, this piece uses the story of Turkish guest workers 'to show how identity is constituted through the management of difference-repelling difference, assimilating it, marginalizing it or denying it' (252). Rather than offering a celebratory focus on a new aspect of the topic of migration, the authors begin by contrasting the representation of Ottoman Turkey in Western European museums as opposed to Turkish institutions. While European institutions represent the stories of Turkish immigrants, those in Turkey are largely silent on those who left the nation. Schematic images throughout the chapter provide graphic illustrations of the politics encountered in various institutions' representations of Turkish history and identity. Critical perspectives on the means by which some museums maintain hegemonic perspectives are equally useful.

The chapter by Whitehead and Bozoğlu seems so essential to the collection that one wishes that it had come earlier. Moreover, while the analytical and critical perspectives in the book are strong, sections tend to blend together. The central themes might stand out more prominently if the text included short section introductions and a conclusion.

In closing, both collections are successful examples of the research coming from the MeLa project. They address the role of technologies and the importance of identity in exhibitions on migration. At the same time, they raise additional questions for consideration. First, the MeLA project has been crucially important, but what of institutions that pursue different roads or values? Second, both works refer frequently to globalization and the need to define Europe's place in an increasingly networked world. Several articles focus on Europe and other regions; the exhibition on child migrants in the Innocenti collection derived from a collaboration involving Merseyside Maritime Museum in the UK and the Australian National Maritime Museum. Nevertheless, is something lost when a global concern is addressed primarily from a European perspective? Does the insistence on this perspective reproduce ethnocentricity? Third, the rich collection of examples of migration exhibits in these two texts leaves one eager for more, and specifically, eager to see how the events of the summer of 2015 will be encoded and represented in exhibitionary institutions. Certainly, recent events have returned some of the focus of global migration to the European continent. The notion of a united Europe without internal borders is being contested daily. Emotionally provocative stories of immigrants stem in part from the fact that cultural, political, and economic conflicts related to diversity have never been resolved. Innocenti, Whitehead, and his co-editors, have laid the groundwork for studying and discussing these circumstances, and for this, we are fortunate. 


\section{Notes}

1 A sister project, Eunamus, ran from 2010-2013. Focusing on European national museums, researchers in this project explored the ways in which these institutions may define national identities, contribute to social cohesion, or reinforce boundaries. 